\title{
Frequent and strong antibody-mediated NK cell activation to HIV-1 Env in individuals with chronic HIV-1 infection
}

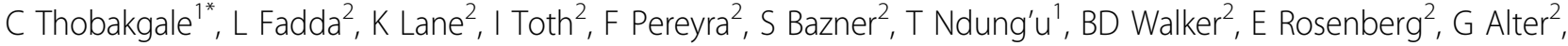 \\ M Carrington ${ }^{3}$, T Allen $^{2}$, M Altfeld $^{2}$
}

From AIDS Vaccine 2012

Boston, MA, USA. 9-12 September 2012

\section{Background}

Natural killer (NK) cells are critical in viral control and NK cells that respond to HIV-1 peptides have been described. However, it is unclear how NK cells recognize HIV-1 antigen. We investigated NK cell responses to HIV-1 peptides during early and chronic HIV-1 clade B infection.

\section{Methods}

NK cells responding to HIV-1 peptides were assessed by multiparameter flow cytometry using whole blood from 74 individuals with treated or untreated early or chronic HIV-1 infection. In addition, 15 HIV uninfected individuals were also studied.

\section{Results}

No NK cell responses to HIV-1 peptides were detected in HIV-1 uninfected individuals. The HIV-1 NK cell specific responses to peptide were less frequent during the first year of infection but were of high magnitude and frequent in individuals with controlled or progressive infection ( $22 \%$ vs $79 \%$; $\mathrm{P}<0.00001)$. The activation of NK cells to peptide pools required the presence of plasma IgG and the responding NK cells had a low CD16 expression and high CD57 expression. Furthermore, plasma derived from HIV-1 infected individuals was sufficient to trigger a response to HIV-1 Env peptide pool by NK cells from healthy donors suggesting the role of antibodies in mediating this activity.

'University of KwaZulu-Natal, Durban, South Africa

Full list of author information is available at the end of the article

\section{Conclusion}

NK cell responses to specific antigens can be induced in HIV-1 infection. Large cohorts are needed to assess the consequences of these NK cells against HIV-1 control or protection from infection.

\section{Author details}

${ }^{1}$ University of KwaZulu-Natal, Durban, South Africa. ${ }^{2}$ Ragon Institute of MIT, MGH and Harvard, Boston, MA, USA. ${ }^{3}$ Cancer and Inflammation Program,

Laboratory of Experimental Immunology, Frederick, MD, USA.

Published: 13 September 2012

doi:10.1186/1742-4690-9-S2-P171

Cite this article as: Thobakgale et al:: Frequent and strong antibodymediated NK cell activation to HIV-1 Env in individuals with chronic HIV-1 infection. Retrovirology 2012 9(Suppl 2):P171.

Submit your next manuscript to BioMed Central and take full advantage of:

- Convenient online submission

- Thorough peer review

- No space constraints or color figure charges

- Immediate publication on acceptance

- Inclusion in PubMed, CAS, Scopus and Google Scholar

- Research which is freely available for redistribution 